Journal of Southeast Asian Studies, 49(2), pp 181-183 June 2018.

(c) The National University of Singapore, 2018 doi:10.1017/S0022463418000012

\title{
Editorial Foreword
}

The way in which violence is remembered in Southeast Asia connects four of our six research articles in this latest issue of JSEAS. Situated in the killing fields of Cambodia, the eastern coastline of the Thai Far South, the uneven sociopolitical terrain of (the former) East Timor, and in the Sierra Madre of the Philippines, the articles trace how diverse communities across the region interact with the dead, erect memorials, create symbols, and perform legends in order to cope with past and current struggles over belonging, memory, place, and power. These works foreground how subsequent generations manage and make sense of the consequences of communal, ethnic, or ideologically based conflict in their lives, focusing less on the nature, histories, or politics of violence. The first of the remaining two research articles examines colonial Singapore's entertainment industry within the context of nineteenth-century transregional circuits, while the last article explores the effects of generational transitions on ethnic-migrant business community practices in contemporary Malaysia.

Caroline Bennett's article offers a stimulating ethnographic account of how rural Cambodians cope with their lived (and non-living) environments following the horrors of the Khmer Rouge. Drawing attention to the presence of corpses of violence (kmoac tay hoang) and mass graves spread across the Cambodian countryside, Bennett investigates how the everyday presence of the Khmer Rouge's victims activated ritual strategies of the living that recognised the agency and priorities of the dead. Focusing on two sites associated with mass killings, Koh Sap and Choeung Ek, the article shows how the dead are 'constitutive of contemporary social order and stability', not merely narrative markers of traumatic memories. Bennett's interviewees present the dead as active players in their lives, providing guidance and direction in the post-conflict rebuilding of Cambodia.

Violence, memory, and place-making are key themes of Muhammad Arafat bin Mohamad's study of Malay identity and community formation in Thailand's Far South, where tensions between the Thai state and Malay minorities erupted into violence in 1975 and 2004. Based on over a decade of interviews, Mohamad examines how the memory of violence in 2004 (where Malay youths were killed by Thai security personnel) is connected orally and materially to earlier occurrences of violence that involved the loss of life within the Malay-Muslim community at the alleged direction of the state. Highlighting the role of graves, their location, and their stylistic design as references to past injustices, Mohamad draws attention to the way his informants construct a sense of collective victimhood through their narrative strategies and connection to these sites of memory. Whereas Bennett highlights the importance of ritually freeing the Cambodian landscape from the ghosts of mass violence, Mohamad demonstrates how the Tomb of Martyrs and similar gravesites in neighbouring 
provinces are memorialised and infused with narratives of injustice, effectively delineating and mapping an alternative space through ideas of shared victimhood.

Where Mohamad points us to the role of graves, memory and violence in the assertion of sub-national identity in the Thai Far South, Catherine Arthur relates how national identity is articulated out of a particular memory of violence in her study of symbolism within Timor-Leste's national flag. The article critically examines how memories of violence, suffering (terus), and struggle (funu) against the Indonesian armed forces in East Timor are literally woven into the fabric of Timor-Leste's national flag as part of more recent nation-building initiatives. In tracing the evolution of the national flag's design from its origins as the flag of Fretilin (the main opposition party during Indonesia's occupation), her study illustrates how particular understandings of the flag's symbolism evolved to reflect the broader struggle for independence and more contemporary contests over the definition of the nation by stakeholders.

Interpreting violent struggle through the lens of local texts, religion and rituals has been a trope within the study of resistance movements throughout the region's history and historiography, most notably in the case of anti-colonial activities in the Philippines. Inspired by the seminal work of Reynaldo C. Ileto in his Payson and Revolution (1979), historians of Southeast Asia were encouraged to think about how the life of Jesus provided a framework, vocabulary, and course of action for thinking about colonialism and resistance to it in its many forms. We were urged to recognise how deeper, more enduring meanings associated with sacred topographies, legends, rituals, and texts could reveal how local, non-elite populations framed, understood, and responded to colonialism. Interpreting acts of peasant violence required insight into the values and ideals of the masses.

Departing from Ileto's treatment of the Bernardo Carpio legend, its connection to the resistance leader Bonafacio, and the implications towards our understanding of lower-class consciousness, Joseph Scalice offers a provocative alternative to how we might understand the seminal events associated with the Philippine Revolution. Arguing that texts referred to by earlier scholars were not indicative of the masses, Scalice maintains that different ways of recovering and interpreting non-elite experiences - through the performance of oral traditions - are helpful in interpreting alternative contexts and memories within non-elite society. Scalice's intervention offers a sustained critical methodology of how we might recover the experiences of the masses, how meaning is inscribed/mis-inscribed into the landscape, and how memories of violence, resistance, and non-elite experiences are constructed.

Our final two essays examine the circulation of entertainment networks in colonial Singapore and the localisation of business networks in contemporary Malaysia. Nadi Tofighian's study of nineteenth-century entertainment circuits situates Singapore within a broader global network. Assessing the transnational and interconnected nature of Southeast Asia through the flows of entertainment companies, Tofighian maps the movement of travelling theatre troupes (bangsawan), American musical companies, circuses, and cinematic exhibitions in Southeast Asia. The article examines the local entertainment scene within Singapore and reconstructs the everyday economic experiences of operating within a nineteenth century entertainment hub. 
Shifting to more recent times, Jesrina Ann Xavier and Edmund Terence Gomez trace the development of eleven Indian-owned medium-scale enterprises in Malaysia over time and across sectors in order to assess the effects and implications of generational change on business practices. The authors examine the ramifications of changing identities within second and third generation business owners upon operations, products, research and development, and market strategy. Through their case studies, Xavier and Gomez test conventional notions of how ethnic entrepreneurship, ethnic enclaves, and ethnic business might work within the context of Malaysia. From a broader perspective, their study reveals how transregional interaction between South and Southeast Asia continues to influence community formation in the region; and in doing so it highlights the enduring importance of 'local' notions of affiliation and belonging upon commercial practices and priorities.

Our research articles are followed by an ample collection of book reviews that reflect the continuing investment of generous colleagues who have contributed their time and expertise in service to the field. The editorial board wishes to thank them and our international referees who have made the present issue possible.

Maitrii Aung-Thwin 